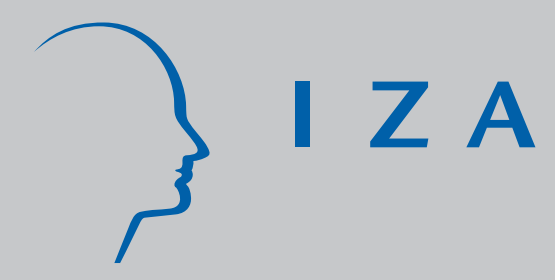

IZA DP No. 2241

Is There a Trade-off Between J ob Security and Wages in Germany and the UK?

Dominik Hübler

Olaf Hübler

August 2006 


\title{
Is There a Trade-off Between Job Security and Wages in Germany and the UK?
}

\author{
Dominik Hübler \\ University of Oxford \\ Olaf Hübler \\ University of Hannover, \\ IAB Nürnberg and IZA Bonn
}

Discussion Paper No. 2241

August 2006

IZA
P.O. Box 7240
53072 Bonn
Germany

Phone: +49-228-3894-0

Fax: +49-228-3894-180

Email: iza@iza.org

Any opinions expressed here are those of the author(s) and not those of the institute. Research disseminated by IZA may include views on policy, but the institute itself takes no institutional policy positions.

The Institute for the Study of Labor (IZA) in Bonn is a local and virtual international research center and a place of communication between science, politics and business. IZA is an independent nonprofit company supported by Deutsche Post World Net. The center is associated with the University of Bonn and offers a stimulating research environment through its research networks, research support, and visitors and doctoral programs. IZA engages in (i) original and internationally competitive research in all fields of labor economics, (ii) development of policy concepts, and (iii) dissemination of research results and concepts to the interested public.

IZA Discussion Papers often represent preliminary work and are circulated to encourage discussion. Citation of such a paper should account for its provisional character. A revised version may be available directly from the author. 
IZA Discussion Paper No. 2241

August 2006

\section{ABSTRACT \\ Is There a Trade-off Between Job Security and Wages in Germany and the UK?}

This paper looks at the wage effects of perceived and objective insecurity in Germany and the UK using the GSOEP and BHPS panels. The distinction between perceived worry about job loss and economic indicators such as regional unemployment rates and the share of temporary contracts is established. The bargaining hypothesis that job security and wages are complements because of union bargaining power and preference is derived from a variant of the right to manage model. This hypothesis is contrasted with Rosen's theory of equalising differences where security and wages are substitutes. The empirical literature surveyed finds evidence for both sides. When addressing a number of econometric issues in earlier studies of the bargaining hypothesis this paper finds strong evidence in favour of the former. Accounting for simultaneous determination of job insecurity and wages significantly negative level effects are found for Germany with some evidence for those in the UK. There is also some evidence for growth rate effects (especially for perceived insecurity), but it does not appear robust. Job insecurity, both perceived and objective is found to have influenced wage development in both countries.

JEL Classification: J28, J31, J63, J81

Keywords: job security, wages, Germany, UK

Corresponding author:

Olaf Hübler

Institute of Empirical Economic Research

Leibniz University of Hannover

Königsworther Platz 1

D-30167 Hannover

Germany

E-mail: huebler@ewifo.uni-hannover.de 


\section{Introduction}

Atypical restraint on compensation increases has been evident for a few years now and appears to be mainly the consequence of greater worker insecurity

- Alan Greenspan (1997)

Recently this phenomenon has also been observed in a number of European countries (Carley, 2005). Germany in particular has seen a number of its largest firms agreeing wage deals that have increased hours and frozen wages against the background of a threatened labour force reduction. It is argued that globalisation and the slack situation of the economy have increased worries about the persistence of employment so that employees were willing to make those wage concessions.

This study will draw together research on job insecurity and wage bargaining to see whether the former has an effect on the latter leading to wage effects of job insecurity. So far research in this area has focussed on measures of objective insecurity such as unemployment and one aim of this paper is to broaden this scope.

The GSOEP and BHPS household panels are used to contrast the situation in Germany with that of the UK. Choosing two advanced European countries allows for comparability, thus we can magnify the effect of the very different bargaining arrangements in the two countries also taking account of different recent economic dynamism.

The paper is structured as follows. Section 2 provides an overview of labour market institutions and the development of job security and wages. Sections $3 \& 4$ survey the theoretical and empirical literature and outline the model to be used. Data and applied methods are laid out in sections 5. Section 6 reports the empirical results including a summary and limitations of the approach, section 7 concludes. 
Using a random effects panel model we find that both perceived and objective job insecurity have a significantly negative effect on the level of wages in Germany with the effect of perceived insecurity in the UK ambiguous. There is also evidence for negative wage growth effects but here the role of regional unemployment in Germany appears limited.

\section{Background: The British and German labour market}

This section gives a brief overview of the countries' labour markets pointing out relevant stylised facts. The section also describes important differences in the wage bargaining process in the two countries.

\subsection{Institutions}

Union density is similar but in decline in both countries with the figures slightly higher in the UK for the entire sample period. (Visser, 2006). The countries are very different though when it comes to the coverage of union bargaining agreements.

In Germany collective bargaining is much more well-established than in the UK. Statutory rights are guaranteed to both bargaining parties and the state is barred from interfering by law (Tarifautonomie). Bargaining is usually conducted between sectoral unions and employer organisations at district level. The organisations usually cover a number of different industries which makes agreements applicable to a large number of enterprises. Agreements are correlated across sectors and regions as one agreement is taken as a precedent in other negotiations (Schnabel, 1997).

If no agreement is reached in a first round of negotiations the union can use industrial action if a 75\% majority of a firm's employed workers vote in favour. In case of the negotiating parties failing to reach an agreement, an arbitration panel suggests a solution, which is non-binding though and can be ignored by either side.

The final agreement has implications for a large part of the workforce. According to a recent European Commission report (Carley, 2005) "[t]he proportion of employees covered by a sectoral 
agreement in 2003 was 62\% in West Germany and 43\% in East Germany (in 2002, it had been 63\% and 43\% respectively). However, a relatively large number of companies with a company agreement or with no collective agreement use sectoral agreements as a point of reference for determining pay and working conditions.” There is a downward trend though with a number of large companies, particularly in the East, opting out of the employers’ organisations in recent years.

Coverage in the UK is much lower, in fact according to Brown (2003) the unions have been more or less marginalised outside the public sector. The aforementioned EU commission report quotes a figure of $35.9 \%$ for 2003. Most of this bargaining is done at the decentralised level of the company.

Strike activity in both countries has fallen compared to earlier decades but detailed figures will not be dealt with here as the link from strike action to union power is not straightforward. Strikes may as well be an indicator of union impotence as of union power.

\subsection{Job insecurity}

Two different types of job insecurity are evaluated in this section. Klandermans and van Vuuren (1999) discuss the concepts of perceived and “objective” job insecurity.

\section{Objective insecurity}

There are a number of factors that could be considered objective job insecurity measures. A first candidate is the observed rate of worker displacement. The unemployment rate is also used as a measure of objective job insecurity. (e.g. Carlin and Soskice, 1990).

The usefulness of these measures is contested though as only a fairly small number of people are or become unemployed every period. Therefore just looking at these rates will understate job insecurity as changes in those rates will also affect perceived security of those currently in employment. Individuals may adapt their (bargaining) behaviour even if they are not themselves affected by adversity because they feel threatened.

Pearce (1998) suggests the share of temporary contracts as the best measure of job insecurity since temporary employment inevitably means uncertainty about future employment. This 
approach is criticised by De Witte and Naswall (2003). They find that temporary contracts per se do not have any implications for bargaining.

In most of what follows we will use the regional unemployment rate as a measure of objective insecurity. Data is available at Bundesland / Census region level creating sizeable variation in the explanatory variable not easily available for other measures.

\section{Perceived insecurity}

The difficulties of finding a straightforward objective measure of job insecurity are outlined above. Another approach that can be taken is to ask workers directly how secure they perceive their job to be. Answers to "How worried are you about the security of your job" (GSOEP) or “[H]ow satisfied or dissatisfied are (you) with (...)Your job security” (BHPS) are scaled in 3 (GSOEP) or 7 (BHPS) steps. Perceived insecurity will be some function of the objective variables and individual variables such as personal optimism, insider information, etc. The form of this function will vary for each individual and we cannot hope to be able to estimate it at an individual level.

\section{Trends in job security ${ }^{1}$}

Before looking at the country's experiences, note that we should neither compare absolute values of job security nor percentage changes. Scaling is different and the measure is ordinal rather than cardinal so that we cannot compare magnitudes of changes but only signs.

In the UK perceived job security has improved significantly ${ }^{2}$ throughout the surveyed period.

On the chart overleaf we see that this trend is correlated with objective measures such as a falling unemployment rate ${ }^{3}$. Brown suggests EU legislation and improved individual statutory rights (e.g. through ACAS) as further explanations of increases in job security.

\footnotetext{
${ }^{1}$ We use job security (rather than insecurity) in this section to account for the way the data is set up in the panels.

${ }^{2}$ The relevant t-statistic is 2.258 for a "difference in means" test

${ }^{3}$ Unemployment data from ONS regional unemployment data base (see overleaf for source), regions weighted by share of people in the sample. Thus, the unemployment will not necessarily be identical to the official unemployment rate due to sampling.
} 


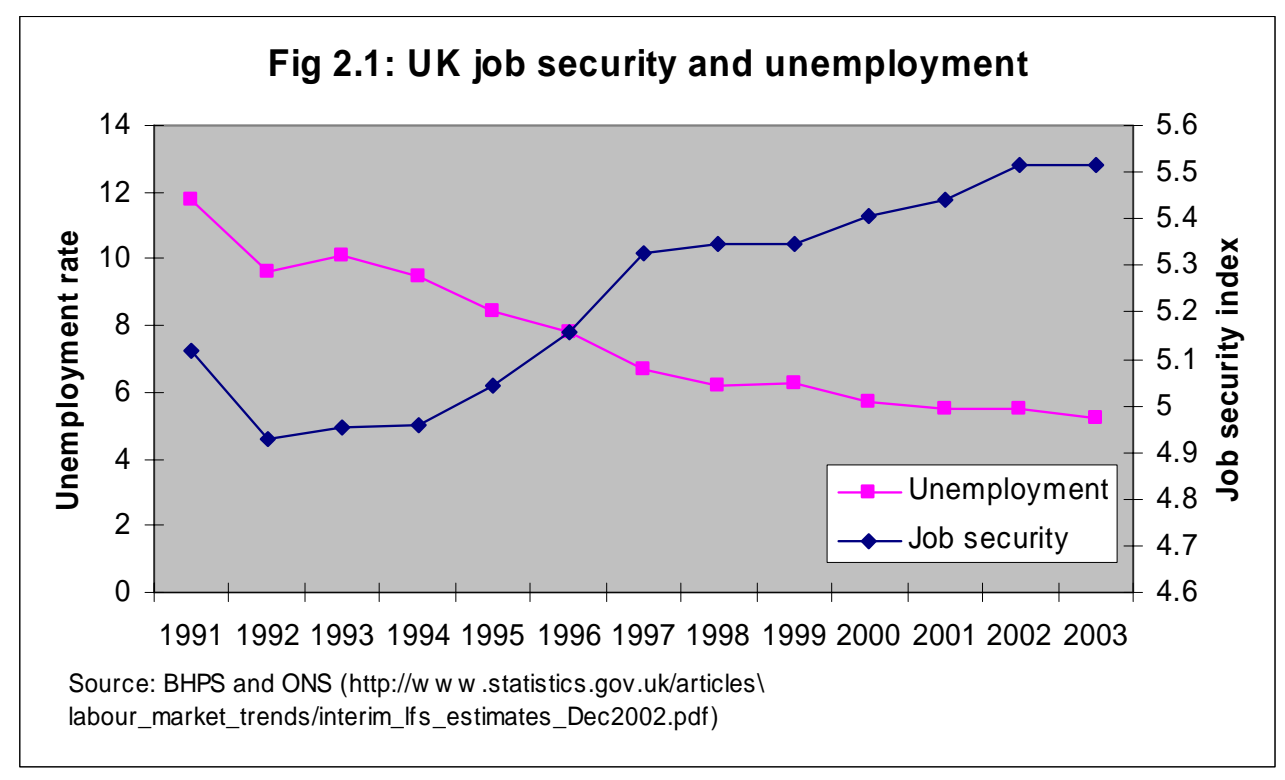

For annual averages negative correlation between the unemployment rate and job security is near perfect (-0.987) and correlation between the share of temporary work and job security ($0.524)^{4}$ is significantly negative. At the individual level correlation between regional unemployment and job security is only -0.101 though. On the whole, we are able to conclude that there have been improvements in both objective and perceived job security in Britain over the sample period.

The picture in Germany is much less clear-cut. There seems to be some upward trend in perceived job insecurity but it is far from homogeneous. The chart overleaf shows two periods of drastic falls in perceived job security in Germany. The first one in 1992 is due to the full introduction of Eastern Germans to the GSOEP. Eastern German job insecurity is substantially stronger than Western for the entire period. This is entirely expected when comparing unemployment rates and levels of economic activity since unification. The second drop, beginning in 2001, points towards a more interesting phenomenon. It appears that perceptions of job security are currently worsening dramatically in Germany.

\footnotetext{
${ }^{4}$ The t-statistic is -2.04 . Correlation is significant at the $10 \%$ level for a one-sided test.
} 


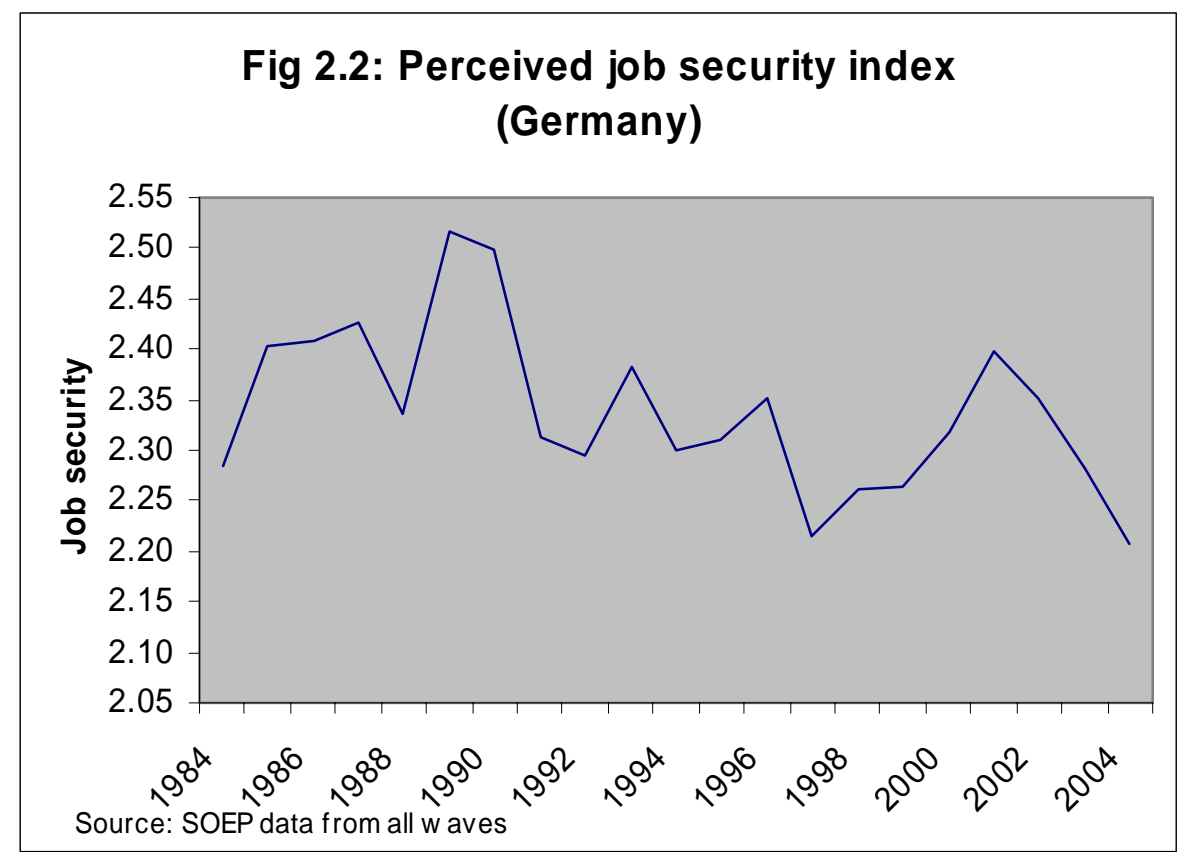

Next we compare perceived job security to objective measures. The correlation coefficient between job security and the share of temporary work is $-0.252^{5}$. It is also instructive to look at the mean of perceived job security over time when splitting the sample into permanent and non-permanent jobs. As expected workers with permanent jobs feel more secure about their jobs, but their relative security advantage has been eroded over time.

Aggregate perceived insecurity is also correlated with the objective measure of the aggregate unemployment rate. $^{6}$ Correlation is significant at the $5 \%$-level at a value of $-0.5413 .^{7}$ Correlation between regional unemployment and job security at the individual level is negative but small at $-0.22 .^{8}$

\footnotetext{
${ }^{5}$ The relevant t-statistic is -0.864 . We therefore cannot reject the hypothesis of no correlation at any common significance level.

${ }^{6}$ The caveat about the unemployment rate diverging from the official figure due to sampling applies again. ${ }^{7}$ t-statistic: -2.135

${ }^{8}$ Due to the large number of observations used here $(71,928)$ standard errors are very low. The t-statistic is -60.6 , which marks a highly significant coefficient.
} 


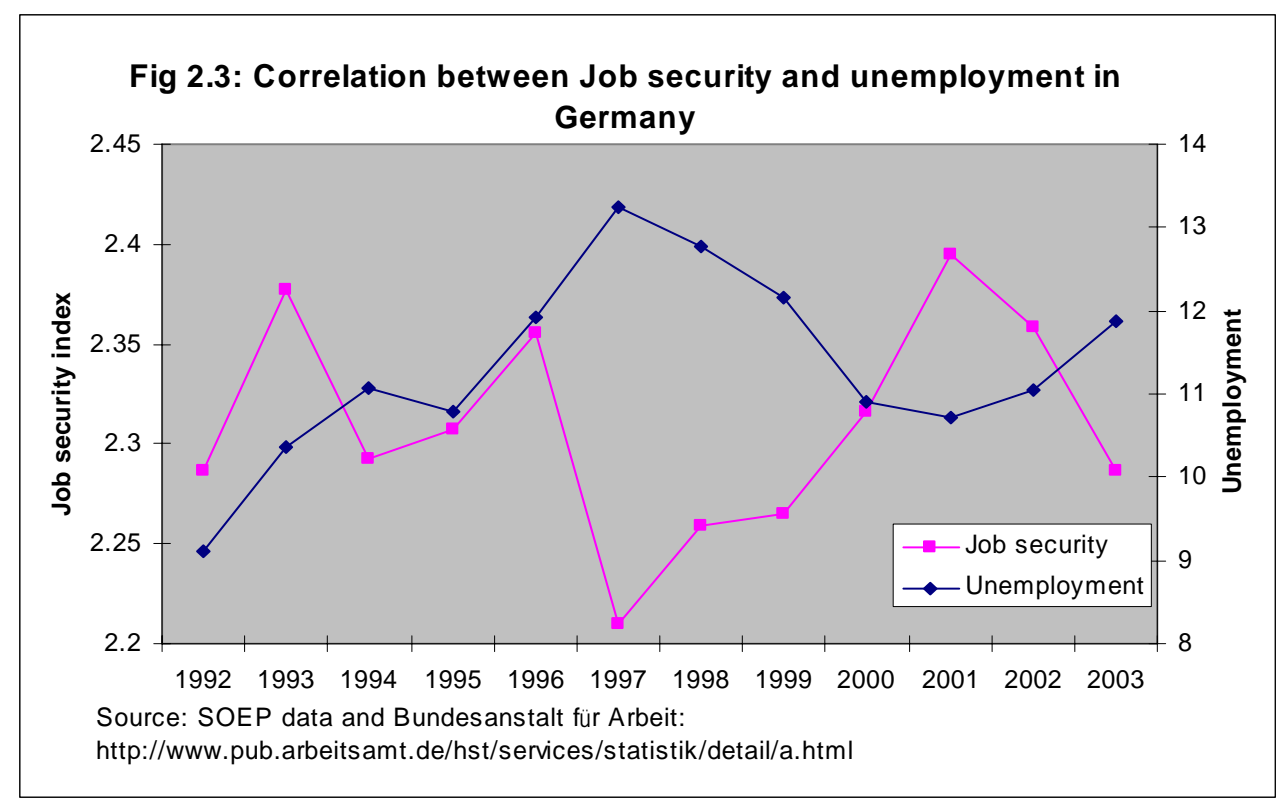

\subsection{Wages}

We are using hourly wages adjusted by the local consumer price index. Using hourly earnings is important due to possible changes in the standard work week. If we use weekly or monthly wages we run the risk of confounding changes in wages and changes in hours worked. Price indices are chosen to capture consumer prices, the relevant variable for union bargaining. These are the RPI published by the $\mathrm{ONS}^{9}$ and the consumer price index published by the Statistisches Bundesamt ${ }^{10}$. The price indices are set to 1 in 2000 for Germany and in 1987 for the UK.

In the UK there is little trend in inflation-adjusted net pay till 1998 followed by a period of notable increases from 1998 to 2002. Wage growth is correlated with increases in job security with a significant coefficient of 0.699 for net pay (t-stat: 3.24). Inflation-adjusted net wages for Germany show an upward trend throughout. Up until 2001 they roughly follow the development of job security ${ }^{11}$. The last two years of the sample show divergence with a drastic fall in job security that is not reflected in falling wages.

\footnotetext{
${ }^{9}$ http://www.statistics.gov.uk/downloads/theme_economy/Rp02.pdf

${ }^{10}$ http://www.destatis.de/download/d/preis/jahr_ab_1948.pdf

${ }^{11}$ Correlation coefficient: 0.276; t-statistic: 0.861 .
} 


\section{Related theoretical literature}

This section develops the Nickell and Andrews (1983) (henceforth NA) "right to manage" model where unions and employers bargain about wages in a positive sum game. After the wage is agreed upon the firm unilaterally sets the level of employment. In the second part different theories of how job insecurity affects wages are presented.

\subsection{Wage determination literature}

Before we look at the specific features of the NA model there is a very brief taxonomy of influential wage determination models. The earliest models of wage determination are rooted in the neo-classical framework of perfect competition. In such cases all inputs to production are paid their marginal products. The growth of real wages is determined by the growth of labour productivity. Individual productivity is not directly observable though hence proxies such as age, tenure and schooling are used to get a wage equation in the Mincerian tradition. The classical assumption of perfect competition in the labour is likely to be inaccurate though. Therefore we need to identify wage determinants beside productivity such as union and employer bargaining power.

The earliest model of countervailing bargaining power with unions and employers was Hicks (1932). Hicks developed a model where strikes or lock-outs are used to enforce bargaining power. However, its specifications are rather ad-hoc and the focus on strikes as a means of bargaining power is too narrow as industrial action only rarely takes place these days.

\section{The right to manage model}

The right to manage model is a better representation of bargaining in current industrialised countries. In the NA model the real wage is bargained for with employment unilaterally set. Successful negotiations will always improve the standing of at least one party as opposed to the outcome when negotiation fails.

$$
S W(U, \pi) \geq S W\left(U_{0}, \pi_{0}\right), \pi \geq \pi_{0}, U \geq U_{0}
$$


In this model $U$ is the utility gained by a representative union member and $\pi$ the utility of a representative employer. SW denotes total social welfare. $\pi_{0}$ and $U_{0}$ are the levels of utility the parties get in the case of failing negotiations. For simplicity we set employer's utility equal to profit. The utility of the union will be looked at in more detail below. The distribution of the bargaining gains depends on respective bargaining power. The outcome of bargaining can be modelled as

$$
\max \left(U^{*}-U_{0}\right)^{\mu}\left(\pi^{*}-\pi_{0}\right)^{1-\mu}
$$

The parameter $\mu$ describes the distribution of bargaining power. If $\mu=1$ the entire bargaining power is with the union and it will be able to achieve its target utility $\mathrm{U}^{*}$ by obtaining the highest $\frac{W}{P}$ (denoting the real wage) possible given the participation constraint that the employer must be no worse off than if he didn't take part in negotiations.

The next section will look at the union's utility function in a bit more detail. Generally the union's utility function will be a weighted average of the utilities of its members. We can divide union members into three groups: Those that are covered by union arrangements $(\mathrm{C})$, those that work elsewhere (NC) and those that are unemployed. We then get the following union utility function.

$$
U^{*}=s_{C} * u\left[(1-t) \frac{W_{C}}{P}, T-h_{C}\right]+s_{N C} * u\left[(1-t) \frac{W_{N C}}{P}, T-h_{N C}\right]+\left(1-s_{N C}-s_{C}\right) * u\left[\frac{Z}{P}, T\right]
$$

where $s_{i}$ denotes the share of the labour force that is working and covered or not covered by union bargaining. $\mathrm{W}_{\mathrm{i}}$ is the wage paid to group $\mathrm{i}, \mathrm{z}$ is income from benefits and separation payments, and $\mathrm{t}$ is the tax rate. We assume that both income and leisure $\left(\mathrm{T}-\mathrm{h}_{\mathrm{i}}\right)$ are important to the employee. 


\subsection{Modelling the role of job insecurity in wage determination}

There are two different approaches as to how job insecurity influences wage determination. The bargaining hypothesis stresses job insecurity’s influence on union bargaining power and preference (see below) and predicts a negative link between job insecurity and wages.

The opposing approach of equalising differences views labour compensation as a package that includes monetary wages and other non-monetary amenities of which job security is one. These amenities can be traded off as substitutes given a level of bargaining power so that higher job insecurity has to be compensated by higher wages.

\section{The bargaining hypothesis}

This section will model the effect of job insecurity in the aforementioned NA model. Bargaining preference and bargaining power are two channels through which job security influence wages.

To see where bargaining preference fits into that model the utility function of the union has to be scrutinised more carefully. To make things simple we will for the moment assume that all union members are employed and covered by union agreements. We will also abstract from taxation and leisure. The simplified union utility function is

$$
U^{*}=u\left(\frac{W_{C}}{P}\right)
$$

We then expand (3) into a two-period model where there is a chance of workers becoming unemployed in the second period.

$$
U^{*}=u\left(\frac{W_{t}}{P_{t}}\right)+\beta u\left[(1-\alpha)\left(\frac{W_{t+1}}{P_{t+1}}\right)+\alpha \frac{z}{P_{t+1}}\right]
$$

where $\beta$ is the discount factor and $\alpha$ is the probability of becoming unemployed. $\alpha$ can be interpreted as average perceived job insecurity when referring back to the way the perceived job security variable is measured (see section 2.2). If union members perceptions of job security are rational this should be the union's best guess to real post-bargaining $\alpha$. However, 
actual bargaining may influence $\alpha$ thus blurring the relationship between the pre-bargaining security index and realised $\alpha$.

In the two-period model the union will bargain about both wages (W) and separation payments (z). Any worker not in employment in period $t+1$ will have just been laid off and thus receive $\mathrm{z}$. Higher job insecurity allocates a higher weight to $\mathrm{z}$ in the union utility function. If we believe in a budget constraint for the union than an increase in $\mathrm{z}$ will require a decrease (or at least a slower increase) in $\frac{W}{P}$.

In case of bargaining power on both sides we use (2), the full NA model.

$$
\max \left(U^{*}-U_{0}\right)^{\mu}\left(\pi^{*}-\pi_{0}\right)^{1-\mu}
$$

Cahuc et al. (2002) find $\mu=0.2$ in France suggesting $0<\mu<1$ is correct.

Kaufman and Martinez Velazquez (1988) present evidence that $\mu$ is positively related to job security.

$$
\mu=f(\text { jobsec })
$$

They find that job insecurity plays an important role in determining the vigour with which union members are fighting for wage deals. If that vigour is low it is easy for employers to overcome union calls for high wages. Thus, job insecurity decreases union bargaining power and hence wages.

\section{Equalising differences}

A different view is maintained by Rosen (1986) who suggests a positive ceteris paribus relationship between job insecurity and wages. According to his theory from a static point of view jobs that are high in disamenities (such as job insecurity) would be expected to pay higher wages to compensate for the disamenity. One example here may be the financial sector that combines high pay and low job security. 
Shah (1985) also describes this approach pointing out that risk-averse workers and less riskaverse or risk-neutral firms can both gain from trading off job security and wages. In this model we would see higher job security “bought” by lower wages.

This section has developed the NA model and it has suggested a number of theoretical channels through which job insecurity can affect wages, both positively and negatively.

Next we are looking at empirical literature that has sought to test these differing views and then we seek to establish whether a relationship between wages and job security can be shown for Germany and the UK during the sample period.

\section{Related empirical literature}

The majority of the empirical literature reviewed will seek to quantify positive and negative job security effects through the various channels pointed out above. It is also interesting to note findings by Schmidt (1999) that perceived and objective job security have drifted apart in the US.

\section{Equalising differences}

The theory of equalising differences predicts that higher job security has to be traded off at the price of lower wages. Cahuc et al. (2002) find some evidence for this theory when looking at bargaining at the firm level in France using the firm rate of job destruction as their measure of job insecurity.

Villanueva (2004) tests the prediction of equalising differences investigating whether labour markets place wage premia on adverse working conditions. He uses a sample of German jobswitchers taken from the GSOEP. The estimated market return to the presence of work strain of is between $3.5 \%$ and $5 \%$. However, job insecurity is not found to be systematically related to wages. 


\section{The bargaining hypothesis}

Iverson and Kuruvilla (1995) point out that job insecurity may be perceived as union weakness leading to disenchantment with the union, putting the union in a weaker position when dealing with employers. Such a scenario may actually send union influence on a downward spiral as a weaker union will achieve lower job security and wages in the next bargaining round leading to further disenchantment.

On the other hand Guest and Dewe (1988) find that for the UK union membership increases with job insecurity. They explain their somewhat surprising result as a mechanism to mitigate hardship to come and a "voice" mechanism to express disapproval with the employer's actions (see Hirschman, 1970)

These scenarios are tested by Sverke and Goslinga (2003) who investigate the employer and union effects of higher job insecurity looking at union members in four different European countries $^{12}$. The authors find mixed evidence on this point of view with turnover intention higher and union commitment significantly lower in some countries but not all.

Alvi (1998) tests Snower's insider model using an efficiency wage model with insider outsider effects. He shows that lower formal job security will lead to a lower no shirking condition and hence lower efficiency wages.

An important study trying to quantify the wage effects of job insecurity is Aaronson and Sullivan (1998). The authors assess whether job insecurity has had an effect on wages in the US when controlling for regional unemployment and past wages. They use the following equation:

$$
w_{r t}=\alpha S_{r t}+\lambda U_{r t}+\phi w_{r t-1}+v_{r}+v_{t}+v_{r t}
$$

where $\mathrm{w}$ is the $\log$ of the wage rate, $\mathrm{s}$ is a measure of job security and $\mathrm{U}$ is the log of the unemployment rate. $\mathrm{t}$ is a time subscript, where $\mathrm{r}$ denotes a region. Due to the lack of panel

\footnotetext{
${ }^{12}$ The countries used by Sverke/ Goslinga (2003) are Belgium, Italy, Sweden, Netherlands
} 
structure they cannot track individuals over time and have to create a "panel" by using regional averages.

Two different measures of job insecurity are used: Displacement rates and a subjective probability of job loss index. Data is taken from the Current Population Surveys for a period from 1977 to 1996 . Their findings suggest that perceived job insecurity may dampen wage growth even when we control for regional unemployment. The coefficient on displacement rates has a significantly negative effect on weekly and annual earnings in the area of $-2 \%$. This may however be due to the confounding effects of hours described before. When using the job loss index it cannot be found to have a significant effect in any regression. Their regressions suffer from a problem of simultaneity bias for wage and job security determination though.

\section{Data and Methods}

Data is obtained from the British Household Panel Survey (BHPS) and the German Socioeconomic Panel (GSOEP) ${ }^{13}$. The panels supply individual data but due to their micro nature they cannot offer any matching employer-employee data. This will lower explanatory power as firm effects are found to be important by Leonard / van Audenrode (1995).

We use 12 waves from 1992 (when a unified German panel became available) to 2003 (the most recent BHPS wave available). The minimum number of cross-sectional observations available in one period is 3,564 for 1993 in the UK. A number of specialist subsamples, e.g. GSOEP's high income sample introduced in 2001 have had to be removed for this study in order not to bias wage figures. The final sample contains members of the workforce who reports a value for job security. The variables used in this study are described in Table 5.1.

\footnotetext{
${ }^{13}$ For further information on the data sets see: www.iser.essex.ac.uk/ulsc/bhps/ and http://www.diw.de/english/sop/index.html.
} 


\begin{tabular}{|c|c|c|c|}
\hline Name & Description & $\begin{array}{l}\text { Mean \& (std } \\
\text { deviation) in } \\
\text { Germany }\end{array}$ & $\begin{array}{l}\text { Mean \& (std } \\
\text { deviation) in } \\
\text { the UK }\end{array}$ \\
\hline Age & Worker's age & 38.40 (11.37) & $37.36(11.92)$ \\
\hline Age2 & Squared age of the worker & $\begin{array}{l}1603.96 \\
(906.87)\end{array}$ & $\begin{array}{l}1538.16 \\
(943.24)\end{array}$ \\
\hline Dlhpay & $\begin{array}{l}\text { Growth rate of hourly pay (year-on-year } \\
\text { change of the log of the hourly wage) }\end{array}$ & $0.0389(0.30)$ & $0.0320(0.32)$ \\
\hline East & $\begin{array}{l}\text { Dummy whether the worker lives in one of the } \\
5 \text { Eastern Bundesländer }\end{array}$ & $0.3209(0.47)$ & \\
\hline Hours & Expected hours worked per week & $39.28(10.53)$ & $34.49(10.80)$ \\
\hline Jobmed & $\begin{array}{l}\text { Dummy: job security is in medium category } \\
\text { (Germany) }\end{array}$ & $0.4112(0.49)$ & \\
\hline Jobsec & $\begin{array}{l}\text { Perceived job security, exact questions } \\
\text { described in section } 2 \text {. In both countries poor } \\
\text { job security is denoted as } 1 .\end{array}$ & $2.2833(0.71)$ & $5.3367(1.57)$ \\
\hline Jobsec1 & Dummy: Job security in lowest category (UK) & & $0.0381(0.19)$ \\
\hline Jobsec2 & $\begin{array}{l}\text { Dummy: Job security is in second lowest } \\
\text { category (UK) }\end{array}$ & & $0.0313(0.17)$ \\
\hline Jobsec3 & $\begin{array}{l}\text { Dummy: Job security is in third lowest } \\
\text { category (UK) }\end{array}$ & & $0.0755(0.26)$ \\
\hline Jobsec4 & $\begin{array}{l}\text { Dummy: Job security is in medium category } \\
\text { (UK) }\end{array}$ & & $0.0900(0.29)$ \\
\hline Jobsec5 & $\begin{array}{l}\text { Dummy: Job security is in third highest } \\
\text { category (UK) }\end{array}$ & & $0.1760(0.38)$ \\
\hline Jobsec6 & $\begin{array}{l}\text { Dummy: Job security is in second highest } \\
\text { category (UK) }\end{array}$ & & $0.3532(0.48)$ \\
\hline Jobworry & $\begin{array}{l}\text { Dummy: job security is in the worst category } \\
\text { (Germany) }\end{array}$ & $0.1527(0.36)$ & \\
\hline Lhpay & $\begin{array}{l}\text { Log of inflation-adjusted hourly pay in local } \\
\text { currency. See section } 2 \text { for details }\end{array}$ & $1.9114(0.51)$ & $1.2786(0.466)$ \\
\hline Male & Dummy: gender is male & $0.5550(0.50)$ & $0.5033(0.50)$ \\
\hline Mtsunemp & $\begin{array}{l}\text { Number of months individual was } \\
\text { unemployed in the previous year }\end{array}$ & 0.2966 (1.39) & \\
\hline Overtime & Hours of overtime worked per week & $2.1514(3.54)$ & $4.0570(6.41)$ \\
\hline Perm & Dummy: Worker has a permanent job & $0.8685(0.34)$ & $0.9383(0.24)$ \\
\hline Public & Worker is employed in the public sector & $0.2763(0.45)$ & \\
\hline School & $\begin{array}{l}\text { Years spent in full-time education (including } \\
\text { university, training colleges). In the UK } \\
\text { derived from information about qualifications }\end{array}$ & $11.88(2.57)$ & $11.71(3.39)$ \\
\hline School2 & School squared & $147.76(68.16)$ & $148.58(77.93)$ \\
\hline Size & $\begin{array}{l}\text { Approximate number of workers in firm } \\
\text { (categorical) }\end{array}$ & $4.7110(2.40)$ & $5.1058(2.44)$ \\
\hline Tenure & Number of years spent with current employer & $9.0242(9.27)$ & $4.4092(5.91)$ \\
\hline Tenure2 & Tenure squared & $\begin{array}{l}167.31 \\
(294.91)\end{array}$ & $54.42(143.57)$ \\
\hline $\mathrm{U}_{\text {reg }}$ & $\begin{array}{l}\text { Unemployment rate by Bundesland as } \\
\text { published by Bundesanstalt für Arbeit and } \\
\text { region as by the National Office of Statistics }\end{array}$ & $11.9401(4.53)$ & $7.0869(2.44)$ \\
\hline Wksunemp & $\begin{array}{l}\text { Number of weeks spent unemployed in the } \\
\text { previous year }\end{array}$ & & $1.9675(8.92)$ \\
\hline Year & $\begin{array}{l}\text { Calendar year (included in the ordered probit } \\
\text { model to capture a time trend) }\end{array}$ & $1997.66(3.27)$ & 1997.95 (3.72) \\
\hline
\end{tabular}


This paper builds on the Aaronson/Sullivan approach to find the wage effects of perceived and objective job insecurity. There are a number of data and methodical improvements that can be made. First, both the BHPS and the GSOEP are true panels that allow the estimation of individual effects. Second, we look for both level and growth effects as bargaining may affect both these variables. We use the levels of controls to explain wage levels and changes and levels to explain changes. Variables such as gender and schooling that are almost unchanged in this sample are entered as levels only in the growth regression. Third, we use a Hausman test to check whether an IV specification is required instead of a GLS specification to account for the potential bias imposed by simultaneity of job security and wages by means of using instruments.

The bias can arise from three sources: Firstly, in the case of high wage agreements labour becomes comparatively more expensive which may lead to a shift towards capital. Secondly, the less profitable firms in an industry may not bear high wage agreements and cease to operate. Both these factors will tend to increase perceived job insecurity following strong wage growth. Thirdly, there may be a common factor like the business cycle driving both wages and job insecurity.

Random effects panel models will be used to estimate the effect of job insecurity on the consumer real wage and the change in the consumer real wage. Breusch Pagan tests for random effects confirm non-poolability in all cases. Due to the expected simultaneity the classical assumptions are violated leading to invalidity of the Hausman random effects (RE) v. fixed effects (FE) test (Wooldridge 2005, p. 289). Thus we need to base our choice of estimation procedure on other criteria, e.g. AIC or SC (Hsiao / Sun 2000, S. 97). Here the RE technique is preferred due to the large number of unchanging or monotonously changing variables that explain wages such as gender, schooling and age. Their effects will be dropped in an FE approach leading to a misspecification of the model. The alternative approach, the Hausman-Taylor procedure, is not applied, as it requires specification of which regressors are 
either correlated or not correlated with the individual effect (Cameron / Trivedi 2005, p.761). This is difficult to decide.

Beside the job security variables the aforementioned Mincerian controls such as schooling, experience/age and tenure as well as other controls such as job market history will be used in estimation.

We also need to deal with the nature of the job insecurity as a categorical variable. One approach is to simply enter the variable as if it was cardinal. This may be a reasonable approximation to start with since the categories are ordered in increasing order of security. However, it imposes undue restrictions on the constancy of the effect of job security (see e.g. Greene, 1991, p.243). Therefore we will also create dummies for each category of job security and enter those instead of the categorical variable in a second step.

For each country we will run four sets of regressions. The first two seek to explain (log)levels of wages using job security, regional unemployment and controls. Set 1 uses original variables, set 2 uses instruments. In the third and fourth set of regressions we explain the change in log wages without and with instruments using measures of whether job insecurity has increased or decreased.

Returning to the instrumentation problem there are two candidate instruments for the levels regression. Lagged job insecurity ( $1 j o b s e c)$ is the first one as it is theoretically impossible for wage increases in the future to have affected perceptions of job security today. The second one is predicted job security from the ordered probit using exogenous variables. It fits the observed category of job security to a number of explanatory variables such as age, tenure and education. The estimates are presented in Table 5.2. We should not attempt to compare coefficients between the two countries as thresholds and scaling vary. The threshold values “threshold i” are the upper limits to unobservable perceived security (j*) for those that report job security of group i. The absolute magnitudes have no intrinsic meaning but put the size of marginal effects in perspective. E.g. an individual that was just below threshold 1 for the UK 
with a temporary job (estimated $\mathrm{j}^{*}=46.5$, observed jobsec $=1$ ) will move to $\mathrm{j}^{*}=47.42$, observed category of job security $=4$ when taking up a permanent job with otherwise identical characteristics.

It is interesting to see that ceteris paribus men seem to be more worried about their jobs. This fact is observed in both countries despite unemployment rates by gender being similar ${ }^{14}$. One explanation may be that the possibility of job loss for a male is considered more costly due to his traditional role as the breadwinner, thus increasing worries or unhappiness about job security at similar objective levels. Nickell, Jones and Quintini (2000) make this point by distinguishing worry about job loss from worry about costly job loss. The job loss for a sole breadwinner is thus more costly as the share of family income that is lost is higher.

\begin{tabular}{|c|c|c|}
\hline \multicolumn{3}{|c|}{ Fig 5.2: Influences on job security in an Ordered Probit model ${ }^{15}$} \\
\hline & UK & Germany \\
\hline Male & $-0.184^{\star \star \star}$ & $-0.054^{\star \star \star}$ \\
\hline Size & $-0.024^{\star \star *}$ & $-0.005^{\star \star}$ \\
\hline Tenure & 0.001 & $0.005^{\star \star \star}$ \\
\hline Hours & $-0.004^{\star \star \star}$ & $-0.009 \star \star \star *$ \\
\hline Overtime & $0.006^{\star \star \star}$ & $0.011^{\star \star \star}$ \\
\hline Year & $0.024^{\star \star \star}$ & $-0.012^{\star \star \star}$ \\
\hline$U_{\text {reg }}$ & $-0.012^{\star \star \star}$ & $-0.017^{\star \star \star}$ \\
\hline East & & $-0.421^{\star \star *}$ \\
\hline Perm & 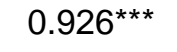 & $0.537^{\star \star \star}$ \\
\hline School & -0.003 & $0.072^{\star \star *}$ \\
\hline Age & $-0.064^{\star \star \star}$ & $-0.077^{\star \star \star}$ \\
\hline Age2 & $0.001^{\star \star \star}$ & 0.001 \\
\hline Log likelihood & $-98,709 * \star \star$ & $-46,068^{\star \star \star}$ \\
\hline No. of obs. & 61,392 & 47,983 \\
\hline Threshold1 & $46.54^{\star \star \star}$ & $-26.83^{\star \star \star}$ \\
\hline Threshold2 & $46.87^{\star \star \star}$ & $-25.54^{\star \star \star}$ \\
\hline Threshold3 & $47.33^{\star \star \star}$ & $\mathrm{n} / \mathrm{a}$ \\
\hline Threshold4 & $47.67^{\star \star \star}$ & $\mathrm{n} / \mathrm{a}$ \\
\hline Threshold5 & $48.21^{\star \star \star}$ & $\mathrm{n} / \mathrm{a}$ \\
\hline Threshold6 & $49.23^{\star \star \star}$ & $\mathrm{n} / \mathrm{a}$ \\
\hline
\end{tabular}

\footnotetext{
${ }^{14}$ See e.g. http://www.destatis.de/indicators/d/lrarb02ad.htm for German rates by gender.

$15 * * *=$ significant at $\alpha=1 \%$,**= significant at $\alpha=5 \%$,*= significant at $\alpha=10 \%$
} 
In the wage regression using dummies we use the estimated probabilities for $\mathrm{n}-1$ categories from the ordered probit as instruments. In the regression with the observed category we generate the instrument by finding the expected value of job security multiplying each category number by its predicted probability from the ordered probit model for this person. For Germany:

$$
E(\text { jobsec })_{D}=1 * \hat{\operatorname{Pr}}(\text { jobsec }=1)+2 * \hat{\operatorname{Pr}}(\text { jobsec }=2)+3 * \hat{\operatorname{Pr}}(\text { jobsec }=3)
$$

The UK model includes all 7 categories but it is identical otherwise. Individual probabilities for one category can be used as instruments for the dummies specification. The ljobsec specification is picked because it shows stronger correlation with current observed job insecurity ${ }^{16}$ - see Table 5.3.

\begin{tabular}{|l|l|l|}
\hline \multicolumn{3}{|l|}{ Table 5.3: Choice of instruments for the levels regression } \\
\hline $\begin{array}{l}\text { Correlation of jobsec } \\
\text { with: }\end{array}$ & in Germany & in the UK \\
\hline Ljobsec & 0.5318 & 0.4702 \\
\hline Predicted jobsec & 0.3078 & 0.2750 \\
\hline
\end{tabular}

Finding instruments for the growth rates regression is more difficult. The lagged change in job insecurity is a poor predictor of the current change in job security. There is little theoretical case to suggest that the rate of change in job security is persistent and empirically correlations are weakly negative for both countries. Thus, we will use the change in predicted job securities. Regressions 4.1 will use the change in expected job security for which the level was derived in (7). Regressions 4.2 will use dummies whether insecurity has decreased (jobbetter) or increased (jobworse) using dummies when the change in predicted job security is two standard deviations outside the mean ${ }^{17}$.

\footnotetext{
${ }^{16}$ The same conclusions apply for dummies (lagged v. predicted). Results are omitted for space reasons.

17 The mean for the change in predicted job security is -0.006 with std. dev. $=0.1072$ for Germany. For the UK mean $=0.0437$ and std. dev. $=0.3568$.
} 


\section{Empirical Results ${ }^{18}$}

\section{Results for Germany}

We find job security, both perceived and objective to have a positive influence on the level of wages in Germany - see Table 6.1. The Hausman statistics point towards an endogeneity problem. Therefore the interpretation will focus on set 2 results. All set 2 regressions find that objective job insecurity represented by regional unemployment rates dampens wage levels by about 2 to $2.5 \%$. The interpretation of the perceived job security coefficients is less straightforward.

\begin{tabular}{|c|c|c|c|c|c|}
\hline \multicolumn{3}{|c|}{ Hausman (IV vs. GLS) statistics } & $\begin{array}{l}1122.35 \\
p=0.000\end{array}$ & $\begin{array}{c}929.85 \\
p=0.000\end{array}$ & $\begin{array}{c}735.63 \\
p=0.000\end{array}$ \\
\hline & \multicolumn{2}{|c|}{ Set $1-$ RE GLS } & \multicolumn{3}{|c|}{ Set 2 - RE IV } \\
\hline & D1.1 & $\mathrm{D} 1.2$ & D2.1 & $\mathrm{D} 2.2$ & $\mathrm{D} 2.2 \mathrm{a}$ \\
\hline Jobsec & $0.0318^{\star \star \star}$ & & $0.1186^{\star \star \star}$ & & \\
\hline Jobworry & & $-0.0651^{\star \star \star}$ & & $-0.3219^{\star \star \star}$ & $-0.1412^{\star \star \star}$ \\
\hline Jobmed & & $-0.0292^{\star \star *}$ & & 0.0174 & $-0.0457^{\star \star \star}$ \\
\hline School & $0.0951^{\star \star \star}$ & $0.0951^{\star \star \star}$ & $0.0528^{\star \star \star}$ & $0.04990 * \star \star$ & $0.0151^{\star \star \star}$ \\
\hline School2 & $-0.0017^{\star * \star}$ & $-0.0017^{\star \star *}$ & -0.0001 & -0.0000 & $0.0014^{\star * *}$ \\
\hline Age & $0.0929 * \star \star$ & $0.0929 * \star \star$ & $0.0801^{\star \star \star}$ & $0.0773^{\star \star *}$ & $0.0331^{\star * \star}$ \\
\hline Age2 & $-0.0010^{\star \star *}$ & $-0.0010^{\star * *}$ & $-0.0009 * \star \star$ & $-0.0008^{\star \star \star}$ & $-0.0004^{\star \star *}$ \\
\hline Male & $0.2100^{\star \star \star}$ & $0.2100^{\star \star \star}$ & $0.2127^{\star \star \star}$ & $0.2108^{\star \star \star}$ & $0.2204^{\star \star *}$ \\
\hline$U_{\text {reg }}$ & $-0.0196^{\star \star \star}$ & $-0.0197^{\star \star *}$ & $-0.0219 * \star \star$ & $-0.0225^{\star \star \star}$ & $-0.0253^{\star \star \star}$ \\
\hline Public & $0.0164^{\star \star \star}$ & $0.0166^{\star \star \star}$ & $0.0312^{\star \star \star}$ & $0.0399^{* \star *}$ & $0.0501^{\star * *}$ \\
\hline Size & $0.0227^{\star \star \star}$ & $0.0226^{\star \star \star}$ & $0.0239^{\star \star *}$ & $0.0229^{\star \star \star}$ & $0.0343^{\star \star *}$ \\
\hline Mtsunemp & $-0.0020^{\star *}$ & $-0.0020^{* *}$ & -0.0004 & 0.0007 & $-0.0057^{* \star *}$ \\
\hline Overtime & $-0.0051^{\star \star *}$ & $-0.0051^{\star \star *}$ & $-0.0056^{\star \star \star}$ & $-0.0055^{\star \star \star}$ & $-0.0057^{\star \star \star}$ \\
\hline Tenure & $0.0093^{\star * *}$ & $0.0093^{\star * *}$ & $0.0109 * * *$ & $0.0111^{\star \star *}$ & $0.0147^{\star * * *}$ \\
\hline Tenure2 & $-0.0001^{\star \star \star}$ & $-0.0001^{\star * \star}$ & $-0.0001^{\star \star \star}$ & $-0.0001^{\star \star *}$ & $-0.0002^{\star \star \star}$ \\
\hline cons & $-1.0855^{\star \star \star}$ & $-0.9894^{\star \star \star}$ & $-0.6700 * \star \star$ & $-0.2790^{\star \star \star}$ & $0.8772^{\star \star \star}$ \\
\hline Sigma_u & 0.3071 & 0.3071 & 0.2453 & 0.2446 & 0.0000 \\
\hline Sigma_e & 0.2422 & 0.2422 & 0.2877 & 0.2903 & 0.7022 \\
\hline Rho & 0.6165 & 0.6164 & 0.4209 & 0.4150 & 0.0000 \\
\hline R-sq. & 0.4541 & 0.4542 & 0.4364 & 0.4099 & 0.4280 \\
\hline
\end{tabular}

\footnotetext{
${ }^{18}$ Again job security (not insecurity) is used in this section to follow the data.
} 
In regression D2.1 there is evidence for job security having a wage-boosting effect. In regression D2.2 the evidence is mixed. Those very worried about their jobs earn about 32\% less than those very secure in their jobs whereas those with medium job security experience no significant wage effect compared to those with very secure jobs. The implausibly large gap for low security workers is likely to be related to workers in irregular and short-term jobs earning considerably less than those in "normal" jobs. Such a phenomenon is known as a secondary labour market with poor wages and security. If we run a regression for a restricted sample with workers in permanent jobs only we get D2.2a.

The magnitude of the "poor job security effect" is much smaller now. Nonetheless a 14\% wage gap between high and low security workers should still be a reason for serious concern to policymakers.

Most of the controls have the expected signs and will not be discussed further. It seems surprising though that earnings in the public sector are better ceteris paribus than in the private sector. Maybe this can be explained by the low number of hours worked in the public sector, which boosts hourly wages when derived from monthly wages. The coefficient on mt sunemp changes sign to the expected one for D2.2a.

We now turn to the influence of the change in job security on the growth rate of wages (change in log hourly pay) - see Table 6.2. There is some evidence that the change in job security has an effect on the growth rate of hourly wages. The coefficients on perceived job security have the expected signs but it seems surprising that an increase in the unemployment rate has a positive effect on wage growth. On the other hand the coefficient on individual past unemployment has the expected (negative) sign. Most controls have plausible signs. 


\begin{tabular}{|c|c|c|c|c|}
\hline \multicolumn{3}{|c|}{ Hausman (IV vs. GLS) statistics } & $\begin{array}{c}228.76 \\
p=0.0000\end{array}$ & $\begin{array}{c}57.22 \\
p=0.0006\end{array}$ \\
\hline & \multicolumn{2}{|c|}{ Set 3 - RE GLS } & \multicolumn{2}{|c|}{ Set 4 - RE IV } \\
\hline & D3.1 & D3.2 & D4.1 & $\mathrm{D} 4.2$ \\
\hline$\Delta$ Jobsec & \multirow[t]{3}{*}{$0.0110^{\star * \star}$} & \multicolumn{3}{|c|}{$0.6771^{\star \star \star}$} \\
\hline Jobbetter & & $0.0185^{\star \star \star}$ & & $0.8285^{\star * *}$ \\
\hline Jobworse & & $-0.0068^{\star *}$ & & $-0.3679 * *$ \\
\hline Age & $-0.0216^{\star \star *}$ & $-0.0215^{\star \star *}$ & $-0.0178^{\star \star \star}$ & $-0.0163^{* \star *}$ \\
\hline Age2 & $0.0002^{\star \star \star}$ & $0.0002^{\star * *}$ & $0.0002^{* \star *}$ & $0.0002^{\star * *}$ \\
\hline Male & -0.0025 & -0.0026 & 0.0007 & -0.0010 \\
\hline$U_{\text {reg }}$ & $-0.0098^{\star \star \star}$ & $-0.0098^{\star \star \star}$ & $0.0099 * \star *$ & 0.0018 \\
\hline$\Delta U_{\text {reg }}$ & -0.0004 & -0.0004 & $0.0167^{\star \star *}$ & $0.0111^{\star * *}$ \\
\hline Public & $0.0117^{\star \star \star}$ & $0.0121^{\star \star *}$ & -0.0100 & 0.0169 \\
\hline Size & $0.0026^{\star \star \star}$ & $0.0026^{\star \star \star}$ & 0.0004 & $0.0026^{\star \star}$ \\
\hline Mtsunemp & $-0.0066^{\star \star \star}$ & $-0.0067 * \star \star$ & $-0.0136 * \star \star$ & $-0.0170 * \star *$ \\
\hline Overtime & 0.0004 & 0.0005 & 0.0007 & 0.0014 \\
\hline$\Delta$ Overtime & $0.0063^{\star \star \star}$ & $0.0063^{\star \star \star}$ & $0.0036^{* \star *}$ & $0.0043^{\star \star \star}$ \\
\hline Hours & $0.0006^{\star \star \star}$ & $0.0006^{\star \star *}$ & 0.0003 & 0.0003 \\
\hline$\Delta$ Hours & $-0.0213^{\star \star \star}$ & $-0.0213^{\star \star \star}$ & $-0.0212^{\star \star \star}$ & $-0.0213^{\star \star \star}$ \\
\hline Tenure & $-0.0004^{* *}$ & $-0.0004^{\star}$ & 0.0003 & $0.0009 * *$ \\
\hline Dummies & & & & \\
\hline cons & $0.6028^{\star \star \star}$ & $0.5997^{\star \star \star}$ & $0.2697^{\star \star \star}$ & $0.2107^{\star \star}$ \\
\hline Sigma_u & 0.0953 & 0.0953 & 0.0000 & 0.0993 \\
\hline Sigma_e & 0.2570 & 0.2570 & 0.5122 & 0.5654 \\
\hline Rho & 0.1209 & 0.1209 & 0.0000 & 0.0299 \\
\hline R-sq. & 0.2490 & 0.2491 & 0.0303 & 0.0434 \\
\hline
\end{tabular}

It seems that the response to increased and decreased job insecurity is asymmetric since the jobbetter effect is more than twice as large as the jobworse one.

If security and wages are complements (as our regressions suggest) promotion and job switching effects may explain the asymmetry. These would increase the positive effect and cover that within-job changes may be symmetric. Without the inclusion of dummies this question cannot be settled though.

On a final note these results should be treated with a degree of caution as indicators suggest that we are dealing with rather poor instruments. The Hausman test statistics are much lower than above and the $\mathrm{R}^{2} \mathrm{~s}$ have fallen considerably. Moreover, the significance of the job security effects disappears when looking at workers in permanent jobs only. 
To conclude we are fairly successful in explaining the level of wages and the role of job insecurity in Germany. Wages are lower for workers who feel insecure and who live in high unemployment regions. The results also support the hypothesis about the existence of a secondary labour market characterised by low pay and non-permanent work. The evidence for growth rate effects is more tenuous with lower explanatory power and an unexpected sign for the change in the unemployment rate. On the other hand the effects of perceived security are significant and point towards the bargaining hypothesis. Robustness is a concern.

\section{Results for the UK}

Again the Hausman statistics suggest that we should use the IV estimates throughout. Objective job insecurity has a significant yet fairly small effect on wages - see Table 6.3. For samples of all workers (UK 2.1 \& UK 2.2) and those with permanent jobs only (UK 2.1a) ${ }^{19}$ the effect is near $1 \%$ per percentage-point increase in regional unemployment. A movement from one perceived job security group to another is found to change wages by about 3.5\%. However, when investigating the more accurate method using dummies we find most dummies to be insignificant with only a middle one significantly negative and very strong. There is no plausible explanation for this pattern. Therefore it is difficult to make a definite statement about the influence of perceived job security on wages.

The similarity between UK2.1 and UK2.1a suggests that the bifurcation of the labour market in the UK is smaller than in Germany. The coefficients of all controls have the expected signs. Comparing the two countries it is worth noting that the gender gap in the UK is only roughly $66 \%$ of that in Germany and it is also interesting to see that in the UK overtime is linked to high-paid work as opposed to low pay in Germany ${ }^{20}$.

\footnotetext{
${ }^{19}$ Note that due to the irregular results in UK2.2 the control regression for workers with permanent jobs only was run for 2.1 in the UK case. For Germany we prefer to run this regression for D2.2 due to the less restrictive nature of the dummy approach when compared to the one using the categorical variable directly.

${ }^{20}$ More details to the comparison of overtime in Germany and the UK see Bell / Gaj / Hart / Hübler / Schwerdt 2001 and Pannenberg / Wagner 2001.
} 


\begin{tabular}{|c|c|c|c|c|c|}
\hline \multicolumn{3}{|c|}{ Hausman (IV vs. GLS) statistic } & $\begin{array}{l}3127.18 \\
p=0.000\end{array}$ & $\begin{array}{l}3546.78 \\
p=0.000\end{array}$ & $\begin{array}{c}233.16 \\
p=0.000\end{array}$ \\
\hline & \multicolumn{2}{|c|}{ Set 1 - RE GLS } & \multicolumn{3}{|c|}{ Set 2 - RE IV } \\
\hline & UK1.1 & UK1.2 & UK2.1 & UK2.1a & UK2.2 \\
\hline Jobsec & $0.0054^{\star \star \star}$ & & $0.0343^{\star \star \star}$ & $0.0337^{\star \star \star *}$ & \\
\hline School & $0.0133^{\star \star \star}$ & $0.0135^{\star \star \star}$ & $0.0120^{* *}$ & $0.0104^{\star \star}$ & $0.0100^{\star *}$ \\
\hline School2 & $0.0014^{\star \star *}$ & $0.0014^{\star \star \star}$ & $0.0016^{\star \star \star}$ & $0.0016^{\star \star \star}$ & $0.0017^{\star \star \star}$ \\
\hline Age & $0.0593^{\star \star \star}$ & $0.0593^{\star \star *}$ & $0.0607^{\star \star \star}$ & $0.0611^{\star \star \star}$ & $0.0601^{\star \star *}$ \\
\hline Age2 & $-0.0006^{\star * *}$ & $-0.0006^{\star \star *}$ & $-0.0007^{\star \star *}$ & $-0.0007^{* \star *}$ & $-0.0006^{\star \star *}$ \\
\hline Male & $0.1199 * \star \star$ & $0.1203^{\star \star *}$ & $0.1421^{\star \star \star}$ & $0.1452^{\star \star \star}$ & $0.1366^{\star \star \star}$ \\
\hline$U_{\text {reg }}$ & $-0.0130 * \star *$ & $-0.0130 * \star \star$ & $-0.0093^{\star \star *}$ & $-0.0101 * \star *$ & $-0.0088^{\star \star *}$ \\
\hline Size & $0.0143^{\star \star \star}$ & $0.0143^{\star \star \star}$ & $0.0156^{\star \star \star *}$ & $0.0159 * \star \star *$ & $0.0156^{\star \star \star}$ \\
\hline Wksunemp & $-0.0015^{\star \star \star}$ & $-0.0015^{\star \star \star}$ & $-0.0008^{\star * *}$ & $-0.0006^{\star \star}$ & $-0.0008^{\star *}$ \\
\hline Overtime & $0.0109 * \star \star$ & $0.0109^{* * *}$ & $0.0106^{\star \star *}$ & $0.0105^{\star \star \star}$ & $0.0107^{\star \star \star *}$ \\
\hline Tenure & $0.0033^{\star \star \star *}$ & $0.0033^{\star \star *}$ & $0.0029 * \star \star *$ & $0.0032^{\star \star \star}$ & $0.0035^{\star \star \star}$ \\
\hline Tenure2 & 0.0000 & 0.0000 & 0.0000 & 0.0000 & 0.0000 \\
\hline cons & $-0.4598^{\star \star \star}$ & 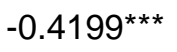 & $-0.6791^{\star \star \star}$ & $-0.6702^{\star \star \star}$ & $-0.4639 * \star *$ \\
\hline Jobsec1 & & $-0.0319 * \star \star$ & & & -0.0825 \\
\hline Jobsec2 & & 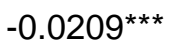 & & & -0.0951 \\
\hline Jobsec3 & & $-0.0222^{\star \star \star}$ & & & $-0.3062^{\star \star *}$ \\
\hline Jobsec4 & & $-0.0270 * \star \star$ & & & 0.0062 \\
\hline Jobsec5 & & $-0.0216^{\star \star \star}$ & & & 0.0626 \\
\hline Jobsec6 & & $-0.0080^{* \star}$ & & & 0.0091 \\
\hline Sigma_u & 0.3057 & 0.3056 & 0.2709 & 0.2709 & 0.2695 \\
\hline Sigma_e & 0.2475 & 0.2475 & 0.2501 & 0.2426 & 0.2570 \\
\hline Rho & 0.6040 & 0.6039 & 0.5400 & 0.5549 & 0.5236 \\
\hline R-sq. & 0.3345 & 0.3345 & 0.3240 & 0.3298 & 0.2930 \\
\hline
\end{tabular}

When turning to the growth of wages - see Table 6.4. -, we find evidence for both types of insecurity having some influence. The coefficients have the expected signs as do the controls apart from individual unemployment history, which appears to have a significantly positive effect on wage growth. This may reflect improvements from a low level for those recently hired from unemployment rather than a strong bargaining position. Interestingly the asymmetry of the change in job security effect runs the other way than in Germany, the absolute effect of jobbetter is smaller than the effect of jobworse. This may be due to attrition bias (see Limitations). Again the results are not robust to a restriction of the sample to permanent work only. 


\begin{tabular}{|c|c|c|c|c|}
\hline \multicolumn{3}{|c|}{ Hausman (IV vs. GLS) statistics } & $\begin{array}{c}150.47 \\
p=0.0000\end{array}$ & $\begin{array}{c}51.39 \\
p=0.0009\end{array}$ \\
\hline & \multicolumn{2}{|c|}{ Set 3 - RE GLS } & \multicolumn{2}{|c|}{ Set 4 - RE IV } \\
\hline & UK3.1 & UK3.2 & UK4.1 & UK4.2 \\
\hline$\Delta$ Jobsec & $0.0050^{\star \star \star *}$ & & $0.0250^{\star \star \star}$ & \\
\hline Jobbetter & & $0.0082^{\star *}$ & & $0.0884^{* *}$ \\
\hline Jobworse & & $-0.0146^{\star \star \star}$ & & $-0.1402^{\star \star \star}$ \\
\hline Age & $-0.0093^{\star \star *}$ & $-0.0093^{\star \star *}$ & $-0.0091 * \star *$ & $-0.0091^{\star \star *}$ \\
\hline Age2 & $0.0001^{* * *}$ & $0.0001^{\star \star \star}$ & $0.0001^{\star \star \star}$ & $0.0001^{* \star *}$ \\
\hline Male & -0.0035 & -0.0034 & -0.0044 & -0.0033 \\
\hline$U_{\text {reg }}$ & $-0.0046^{\star \star \star}$ & $-0.0045^{\star \star \star}$ & $-0.0049 * \star \star$ & $-0.0042^{\star \star \star}$ \\
\hline$\Delta \mathbf{U}_{\text {reg }}$ & $-0.0038^{\star \star}$ & $-0.0039 * *$ & $-0.0030^{\star}$ & $-0.0030^{\star}$ \\
\hline Size & $0.0019 * \star \star$ & 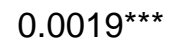 & $0.0015^{\star *}$ & $0.0015^{\star \star}$ \\
\hline Wksunemp & $0.0016^{\star * \star}$ & $0.0016^{\star \star \star}$ & $0.0016^{\star \star \star}$ & $0.0016^{\star \star \star}$ \\
\hline Overtime & $0.0007^{\star *}$ & $0.0007^{* *}$ & $0.0008^{\star \star \star}$ & $0.0007^{* *}$ \\
\hline$\Delta$ Overtime & $0.0065^{\star \star \star}$ & $0.0065^{\star \star \star}$ & $0.0064^{\star \star \star}$ & $0.0063^{\star \star \star}$ \\
\hline Hours & 0.0003 & 0.0003 & $0.0003^{*}$ & $0.0003^{*}$ \\
\hline$\Delta$ Hours & $-0.0155^{\star \star *}$ & $-0.0155^{\star \star \star}$ & $-0.0154^{\star \star \star}$ & $-0.0153^{* * *}$ \\
\hline $\begin{array}{l}\text { Tenure } \\
+ \text { regional }\end{array}$ & $-0.0005^{\star}$ & $-0.0005^{\star}$ & -0.0003 & -0.0003 \\
\hline Dummies & & & & \\
\hline cons & $0.3146^{\star \star \star}$ & $0.3160^{\star \star \star}$ & $0.2493^{\star \star \star}$ & $0.2602^{\star \star \star}$ \\
\hline Sigma_u & 0.0817 & 0.0815 & 0.0000 & 0.0000 \\
\hline Sigma_e & 0.3154 & 0.3154 & 0.3167 & 0.3232 \\
\hline Rho & 0.0629 & 0.0626 & 0.0000 & 0.0000 \\
\hline R-sq. & 0.1306 & 0.1308 & 0.1222 & 0.0928 \\
\hline
\end{tabular}

\section{Summary and Limitations}

We finish this section with a summary of the main results, a brief explanation of these and we discuss some limitations of this empirical investigation.

- $\quad$ Both objective (regional unemployment) and subjective (perceived job insecurity index) job insecurity have negative effects on the log of the hourly inflation-adjusted wage in both countries. We find little to no evidence for the theory of equalising differences in this sample.

- $\quad$ The objective security effect is stronger in Germany; the perceived security effect cannot be compared due to different scaling of the indices and inconclusive British data. The magnitude of the effect observed in Germany is large and should be a cause for concern to policymakers. 
- $\quad$ We find strong evidence for simultaneous determination of job security and wages.

- $\quad$ We find evidence for the existence of a secondary labour market characterised by temporary contracts and low pay in Germany. There is little evidence for such a division in the UK in the data.

- $\quad$ Changes in perceived job insecurity seem to be a factor in determining the change in wages. Looking at the change in wages the role of unemployment in Germany is inconclusive whereas the UK shows the expected effects.

- $\quad$ There seem to be asymmetries in the way increased and decreased security take effect. Interestingly these asymmetries run in opposite directions in the two countries.

- The growth rate effects are not robust to restricting the sample to permanent employment only.

It is pointed out that one reason for job insecurity not having a significant positive effect on wages is self-selection. Naturally more risk-averse workers will pick less risky jobs with those that are almost risk neutral choosing risky jobs. Hence risk premia reflect the marginal rather than the average risk premium. This makes them small to the point of insignificance.

The larger size of the German unemployment effect may be due to the higher difficulty of finding a new job in a less buoyant labour market. Therefore the cost of job loss is likely to be higher, which makes people willing to concede more current income for a safer job.

It could also be due to an asymmetry in the reaction to movements in unemployment. If the majority of the bargaining power is with the employers as is suggested by Cahuc et al. (2002) and Abowd and Lemieux (1993) the negative wage effects of increasing unemployment may be stronger than the positive ones of falling unemployment.

The stagnation of the German economy and the rigid labour laws have made it difficult for many unemployed to find a permanent job again. This dilemma has led to the formation of a 
secondary labour market. The UK has not had those problems due to lower unemployment and higher labour market flexibility.

The non-effect of regional unemployment on wage growth may be due to the German system of precedents in bargaining (see section 2). Some reasons for the asymmetries have been mentioned and the relative importance of those should be investigated in further research.

Due to the limited scope of the paper a number of important issues could not be addressed. E.g. this study has not included matched employer-employee data. Using such data has the great advantage of being able to capture firm effects, which are important determinants of wages as shown by Dustmann and Meghir (2005).

It would also be desirable to correct the result by using a Heckman selection criterion or preferably Mohanty's (2001) selection mechanism that takes account of both the worker's propensity to take up employment and the firm's willingness to employ extra workers. It may also be necessary to review the process of instrumentalisation. Improvements on the ordered probit or the consideration of other instruments are in order.

A more difficult problem is posed by two types of attrition bias the panel is likely to suffer from. Firstly, for obvious reasons the panel only contains entries for perceived job insecurity for those in employment at the time of being surveyed. Since those who felt most insecure about their job last period are most likely to be out of work in the next period, the high-risk group will be underrepresented. The more important problem of survivorship bias is created when the probability of losing your job depends on whether you were willing to accept low wage growth given high job insecurity. If this is the case our estimate of the wage-dampening effect of job insecurity will be biased upwards as those that did not accept a wage cut in the face of uncertainty are more likely to drop out of the sample. (UK4.2 may provide some evidence for this with its strong effect of jobworse).

Secondly, there is standard attrition bias caused by citizens dropping out of the sample for other reasons than unemployment. High-income earners tend to drop out the most downward 
biasing our estimate of wage growth. The variables measuring perceived job insecurity are not strictly comparable as the questions are slightly different since we are using different sources. Finally, the findings do not have to signify causal relationships but may just be testimony to certain industries doing badly for both job security and wages with job switch being impossible due to skill specificity.

\section{Conclusion}

This paper has investigated whether job insecurity (perceived and objective) has an influence on wages in both the UK and Germany. We have built on the theoretical foundations laid by the right to manage model to then draw together the questions of what influences job insecurity and whether job insecurity influences wage bargaining. Different channels through which job insecurity can influence wages have been discussed. The paper has used panel data to address econometric problems encountered in Aaronson and Sullivan's empirical study of the US. These improvements have been applied to German and UK data where such research had been missing.

The paper has found that on most accounts job insecurity, both perceived and objective has a negative effect on hourly wages and changes in wage growth in both countries. This is a new finding compared to previous research where job insecurity was not found to have a significant effect on hourly wages (which are the ones that ought to be used to avoid confounding effects). The level effects appear stronger in Germany where the large wage gap between secure and insecure workers as well as evidence for a bifurcated labour market are serious issues that should be addressed. Further research should investigate whether the importance of job insecurity in wage bargaining is affected by different labour market situation and country-specific bargaining institutions. 


\section{Bibliography}

Aaronson, D., Sullivan, D. (1998): "The decline of job security in the 1990s: Displacement, anxiety, and their effect on wage growth" in Economic Perspectives, Federal Reserve Bank of Chicago.

Abowd, J. / Lemieux, T. (1993): “The effects of product market competition”, Quarterly Journal of Economics 108, 983 - 1014.

Alvi, E. (1998): “Job Security and unemployment in an efficiency-wage model”, Journal of Labor Research 19, 387 - 396.

Bell, D.N.F. / Gaj, A. / Hart R.A. / Hübler, O. / Schwerdt, W. (2001): „Unpaid work in the Workplace: A Comparison of Germany and the UK“, London, Anglo-German Foundation.

Brown, W. (2003): “Industrial relations and the economy 1939 - 1999” in Floud/Johnson: The Economic History of Britain, Volume 3, Cambridge, Cambridge University Press.

Cahuc, P. et al.(2002): “Equalizing Wage Differences and Bargaining Power: Evidence from a Panel of French Firms”, IZA Discussion Paper No. 582.

Cameron, A.C. / Trivedi, P.K. (2005): “Microeconometrics - Methods and Applications”, Cambridge University Press.

Carley, M. (2005): “Industrial relations developments in Europe 2004”, Luxemburg, Office for Official Publications of the European Communities.

Carlin, W./ Soskice, D. (1990): “Macroeconomics and the wage bargain”, Oxford University Press.

De Witte, H. / Naswall, K. (2003): “'Objective’ v. 'Subjective’ Job Insecurity: Consequences of Temporary work for Job Satisfaction and Organizational Commitment in Four European Countries”, Economic and Industrial Democracy 24, 149 - 188.

Dustmann, C. / Meghir, C. (2005): “Wages, experience and seniority”, Review of Economic Studies 72, 77 - 108.

Greene, W.H. (1991):”Econometric Analysis”, New York, MacMillan Publishing Company. Greenspan, A. (1997): “Monetary Policy”, testimony and report before the US House Committee on Banking, housing and Urban Affairs, $104^{\text {th }}$ Congress.

Guest, R. / Dewe, J. (1988): “Why do workers belong to a trade union”, British Journal of Industrial Relations 26, 178 - 193.

Hicks, J. (1932): “The theory of wages”, London, Macmillan.

Hirschman, A. (1970): “Responses to Decline in Firms, Organizations and States", Cambridge, MA, Harvard University Press. 
Iverson, R. /Kuruvilla, S. (1995): “Does dual commitment underlie company and union commitment?”, Research \& Practice in Human Resource Management 3, 15 - 38.

Kaufman, T. / Martinez Velazquez, J. (1988): “Voting for union wage concessions”, Industrial and Labour Relations Review 41, 183 - 194.

Klandermans, B., Van Vuuren, T. (1999): "Job Insecurity: Introduction.", European Journal of Work and Organizational Psychology 8, 145 - 153.

Leonard, J. / van Audenrode, M. (1995): "Persistence of firm and individual wage components”, Cahiers de Recherche 9607, Université Laval - Département d'économique.

Mohanty, M. (2001): “Testing for the specification of the wage equation: double selection approach or single selection approach”, Applied Economics Letters 8, 525 - 529.

Nickell, S. / Andrews, M. (1983): “Unions, Real Wages and Employment in Britain 195179”, Oxford Economic Papers 35, Suppl. 183 - 206.

Nickell, S., Jones, T., Quintini, G. (2000): “A picture of the job insecurity facing British Men”, London, CEP Discussion Papers, Centre for Economic Performance.

OECD (1997): “Is job insecurity on the increase in OECD countries?” in OECD Economic Outlook.

Pannenberg, M. / Wagner G. (2001): “Umfang und Kompensation von Überstunden - Eine vergleichende Analyse für Westdeutschland und Großbritannien”, in L. Bellmann, K. Gerlach, O. Hübler, W. Meyer (eds.), Beschäftigungseffekte betrieblicher Arbeitszeitgestaltung, Beiträge zur Arbeitsmarkt- und Berufsforschung 251, 73 - 94.

Pearce, J. (1998): “Job insecurity is Important but NOT for the reasons you might think” in Cooper C. / Rousseau, D.M.: Trends in Organizational Behaviour 5, NY, John Wiley, 31 - 46. Rosen, H. (1986): “The Theory of Equalising Differences” in O. Ashenfelter, Layard, R. (eds.): Handbook of Labor Economics, Vol. 1, Amsterdam, Elsevier, 641 - 692.

Schmidt, S. (1999) “Long-Run Trends in Workers’ Beliefs about Their Own Job Security: Evidence from the General Social Survey”, Journal of Labor Economics17, S127-S141.

Schnabel, C. (1997): “Tariflohnpolitik und Effektivlohnfindung”, Frankfurt/Main, Europ. Verlag d. Wissenschaften.

Shah, A. (1985): “Wage-Job Security Contracts and Unionism”, Southern Economic Journa $51,849-859$.

Sverke, M. / Goslinga, S. (2003): “The Consequences of Job Insecurity for Employers and Unions: Exit, Voice and Loyalty”, Economic and Industrial Democracy 24, 241 - 270.

Villanueva, E. (2004): “Compensating Wage Differentials and Voluntary Job Changes: Evidence from West Germany”, Economics Working Papers 738, Universitat Pompeu Fabra. 
Visser, J. (2006): “Union membership statistics in 24 countries”, Monthly Labor Review 129, $38-49$.

Wooldridge, J. (2005): “Introductory Econometrics”, Cincinnati, Thomson- South Western. 